\title{
Effects of Enzyme Loading, Incubation Time and Incubation Temperature on Sawdust Hydrolysis by Locally Produced Bacterial Xylanase
}

\author{
S. M. Shaarani1, , L. Y. Min'1, R. C. Man'1, S. K. A. Mudalip1,2, S. Z. Sulaiman ${ }^{3}$ and Z. I. M. Arshad ${ }^{3}$ \\ ${ }^{1}$ Department of Chemical Engineering, College of Engineering, Universiti Malaysia Pahang, Lebuhraya Tun Razak, 26300 Gambang, Pahang, \\ Malaysia. \\ ${ }^{2}$ Centre of Excellence for Advanced Research in Fluid Flow (CARIFF), Universiti Malaysia Pahang, Lebuhraya Tun Razak, 26300 Gambang, \\ Pahang, Malaysia. \\ ${ }^{3}$ Faculty of Chemical and Process Engineering Technology, Universiti Malaysia Pahang, Lebuhraya Tun Razak, 26300 Gambang, Pahang, \\ Malaysia.
}

ABSTRACT - The present study aims to investigate the enzymatic hydrolysis conditions of bacterial xylanase (Bacillus $s p$.) on alternative cheaper substrate which is hardwood sawdust (SD) to produce reducing sugars (xylose). The wood industry in Malaysia has become a major source of foreign exchange across the globe for developing the countries. Therefore, more wood residues (sawdust) are being produced during the logging and processing of wood. Most of the sawdust will be disposed in landfills. In actual, the sawdust can be utilised into valuable products such as xylose, which can be used in food, pharmaceutical and cosmetic industries. Previous researches have studied on xylose production from wooden sawdust using commercial xylanases, but only few with the bacterial xylanase. Therefore, a study on the best conditions of enzymatic hydrolysis in producing xylose from sawdust using bacterial xylanase is essential. Prior to the enzymatic hydrolysis, the hardwood sawdust was pretreated by autoclave at $121^{\circ} \mathrm{C}$ for $20 \mathrm{~min}$ in order to breakdown the lignin linkage and obtain the hemicellulosic xylan (delignification). The treated and untreated sawdust were subjected to Scanning Electron Microscopy (SEM) for surface structure analysis while the xylose production was quantified using Dinitrosalycyclic (DNS) method. The fifth cycle pretreated autoclaved sawdust showed 5.5- fold higher of xylose production than the untreated sawdust. The enzymatic hydrolysis conditions such as enzyme loading (18.5 U to 93.5 $\mathrm{U})$, incubation time (30 min to $240 \mathrm{~min}$ ) and incubation temperature $\left(30{ }^{\circ} \mathrm{C}\right.$ to $80{ }^{\circ} \mathrm{C}$ ) were experimented by One-Factor method in Design Expert. The best enzymatic hydrolysis conditions for xylose production were enzyme loading of $1.4 \%$, incubation time of $30 \mathrm{~min}$, and incubation temperature of $56.9^{\circ} \mathrm{C}$. These conditions also succeeded in producing 2.5 -fold higher xylose than the one without the enzymatic hydrolysis.
ARTICLE HISTORY

Received: 9 Sep. 2020

Revised: 12 March 2021

Accepted: 19 April 2021

\section{KEYWORDS}

Bacterial xylanase

Enzymatic

Hydrolysis

Sawdust

Xylose

\section{INTRODUCTION}

Several researches were done on the hardwood sawdust, for example, reed and meranti woods that are used to produce xylo-oligosaccharides and reducing sugars like xylose through enzymatic hydrolysis [1, 6, 27]. Sawdust is a renewable biomass which consists of lignin, hemicellulose and cellulose, having the potential to be monetised into biofuels. The second most abundant form of hemicellulose is xylan which is also the second most abundant polysaccharides in nature after cellulose [9]. Therefore, hemicellulose can be used to produce xylose and xylo-oligosaccharides by breaking down the bond of polysaccharides.

Hemicellulose is located inside the cell wall of the sawdust, surrounded by lignin. Thus, delignification process should be conducted in order to ensure that the hemicellulose is exposed and ready to undergo enzymatic hydrolysis [2, 25]. Among some common pretreatment methods include steam explosion and liquid hot water (LHW) [5, 21]. They are preferred due to less energy consumption, no toxic element to the enzyme and high sugar yields. During the pretreatment process, structure of cell walls and lignin linkages is destroyed, resulting in the release of hemicellulose and cellulose into the medium as shown in Figure 1.

Apart from that, commercial xylanases have been widely used in enzymatic hydrolysis on various sawdust and act as alternative cheaper substrate compared with commercial substrate, such as reed, rubberwood, oil palm trunk and meranti wood [6, 7, 15, 27]. Recently, a research from Masngut et al. [19] has proposed bacterial xylanase production from landfill bacteria isolates. The bacterial xylanase acts as a key enzyme that randomly cleaves the internal $\beta-1,4-\mathrm{D}$-xylosidic linkages of xylan $[4,30]$. Then, the xylan is further broken down into shorter chain length of saccharides which are xylooligosaccharides and xylose [11]. The mechanism of the xylan break down process using xylanase is as illustrated in Figure 2 . 


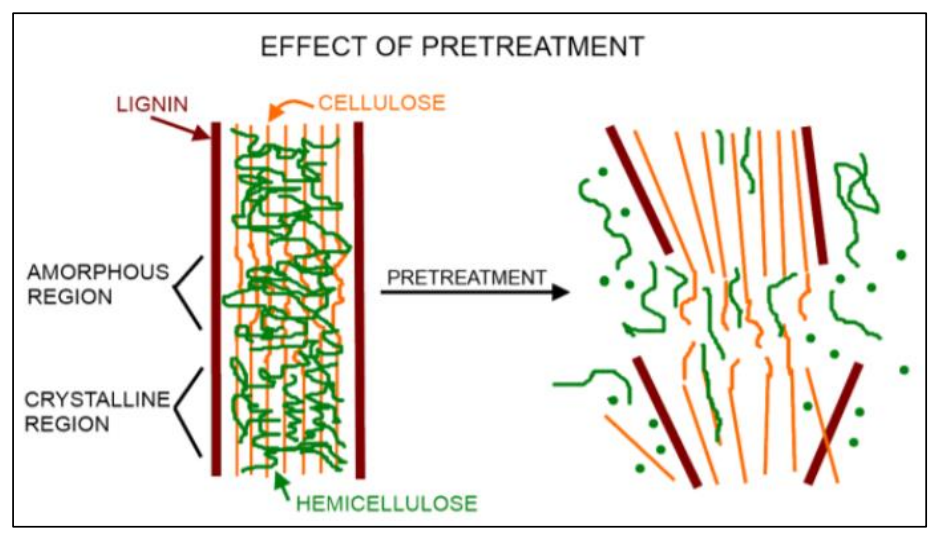

Figure 1. Structure of the cell wall after pretreatment [20].

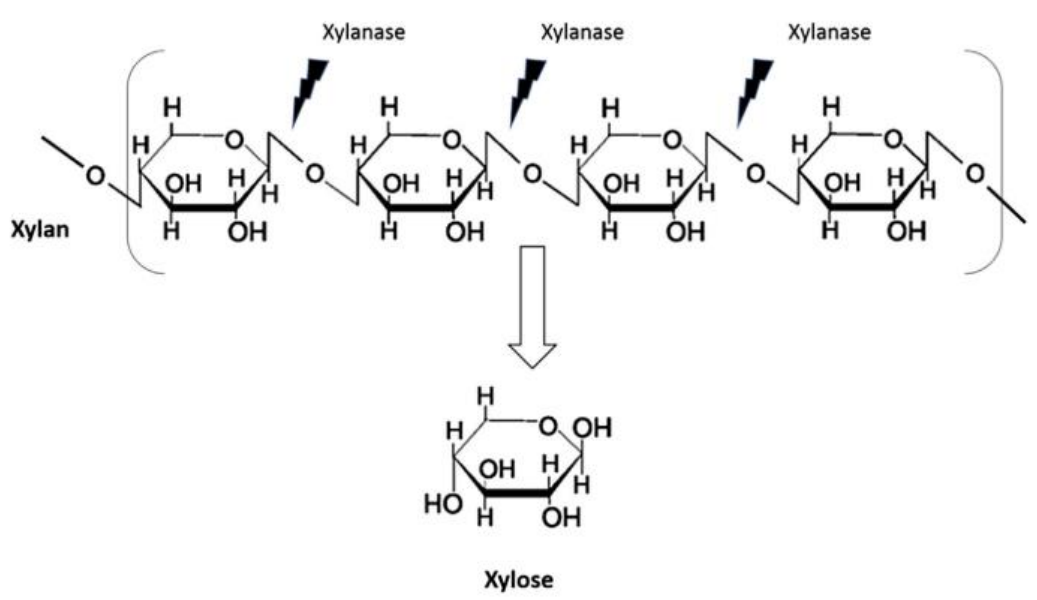

Figure 2. The breaking down process of xylan into xylose by xylanases $[10,12]$.

This paper aims to study the effect of best conditions of enzymatic hydrolysis (enzyme loading, incubation time, and incubation temperature) in producing xylose from sawdust using bacterial xylanase. Hardwood sawdust is selected as a new alternative substrate compared to commercial xylan due to its low cost and high availability.

\section{MATERIALS AND METHODS}

\section{Materials}

Five hundred grams of hardwood sawdust (SD) was procured from the Sawmill Industry which is located in Gambang, Pahang, Malaysia. The SD was used as received from the sawmill and the average dimensions were measured to be 1.0 $\mathrm{cm}$ in length (L) and $0.2 \mathrm{~cm}$ in width $(\mathrm{W})$. The SD was used as an alternative substrate instead of commercial xylan in this experiment. The bacterial xylanase was locally produced in the university's laboratory and secreted from Bacillus sp. which was isolated from local landfill by submerged fermentation, according to previous work of Rosli et.al [23]. This bacterial xylanase $(373 \mathrm{U} / \mathrm{mL})$ was used throughout the enzymatic hydrolysis process.

\section{Enzyme assays}

The activity of xylanase was measured according to a modified Bailey's method [27]. Dinitrosalycyclic acid (DNS) method was used to determine the xylanase activity based on the reducing sugars production. The mixture was prepared with $100 \mu \mathrm{L}$ of diluted bacterial enzyme, $450 \mu \mathrm{L}$ of $1 \% \mathrm{w} / \mathrm{v}$ of commercial xylan substrate [27] and $200 \mu \mathrm{L}$ of phosphate buffer (0.05 M, pH 6.0) in a $2 \mathrm{~mL}$ micro-centrifuge tube. Then, the mixture in the micro-centrifuge tube was mixed before incubation in water bath at $50{ }^{\circ} \mathrm{C}$ for $5 \mathrm{~min}$. After the incubation, $750 \mu \mathrm{L}$ of DNS reagent was introduced, immediately followed by boiling in the water bath at $100{ }^{\circ} \mathrm{C}$ for $15 \mathrm{~min}[14,27]$. The solution was cooled by running water before determining the reducing sugar concentration through UV-VIS spectrophotometer (Hitachi U1800). Then, $1 \mathrm{~mL}$ of solution was transferred to $1 \mathrm{~mL}$ cuvette, the optical density (OD) was read at a wavelength of $575 \mathrm{~nm}$ and the amount of xylose was determined as a reducing sugar. One unit of xylanase activity is defined as the amount of enzyme liberating 1 $\mu \mathrm{mol}$ equivalent of xylose in $1 \mathrm{~min}$ [14]. The experiments were done in triplicates. 


\section{Pretreatment of sawdust (SD)}

Five sets of $20 \mathrm{~g}$ SD were weighed in an analytical balance and placed into five $500 \mathrm{~mL}$ Schott bottles respectively. An amount of $400 \mathrm{~mL}$ pure water were added into the $500 \mathrm{~mL}$ Schott bottles to achieve the solid-to-liquid of 1:20 or 5\% w/v. Each samples were autoclaved with different pretreatment cycles at $121^{\circ} \mathrm{C}$ for 20 min (Established sterilization autoclave conditions with untreated, 1, 2, 3, 4, and 5 treatment cycles). Then, the pre-treated SD was cooled to room temperature. The supernatant and pre-treated SD were separated and stored in refrigerator at $4{ }^{\circ} \mathrm{C}$ for further use.

\section{Enzymatic hydrolysis of autoclaved sawdust to produce reducing sugar}

The enzymatic hydrolysis of fifth cycle pretreated sawdust was performed using bacterial xylanase from Bacillus sp. The ratio of xylanase-to-supernatant was $2 \% \mathrm{v} / \mathrm{v}$ [1]. The total working volume for the experiment was set at $5 \mathrm{~mL}$. By modifying the enzyme hydrolysis method used in Amini et al.,[1] the mixture was incubated for 30 min at $50{ }^{\circ} \mathrm{C}$ with the agitation speed of $200 \mathrm{rpm}$. After incubation, the mixture was boiled at $100{ }^{\circ} \mathrm{C}$ water bath for 10 min to stop the reaction [27]. After the enzymatic hydrolysis, the media were analysed using DNS method. Then, the OD values were read at 575 nm wavelength via UV-VIS Spectrophotometer (Hitachi U1800).

\section{Parameters affecting enzymatic hydrolysis on sawdust}

Xylose can be produced from the hemicellulose through enzymatic hydrolysis after the pretreatment process that have been performed on the sawdust. This is because the bacterial xylanase reacts on the xylan that is released into the media after the pretreatment, and subsequently formed xylose. Therefore, the reaction parameters for producing reducing sugar (xylose) are very important as they will affect the thermostability of the bacterial xylanase. Among the parameters identified are the type of substrate used, agitation rate, $\mathrm{pH}$, incubation time, incubation temperature and enzyme loading $[6,13,27]$.

\section{Data analysis}

In order to find out the effect of the reaction parameters (enzyme loading, icubation time and temperature) on sawdust hydrolysis, five sets of experiments were done for each parameter using a statistical design software, the One Factor design by Design-Expert 7.1.6. Then, the results were analysed using Analysis of Variance (ANOVA) to get the best response in term of xylose concentration. The enzymatic hydrolysis was carried out at different enzyme loadings of 19 U, $37 \mathrm{U}, 56 \mathrm{U}, 75 \mathrm{U}, 93 \mathrm{U}$ at same incubation time of $30 \mathrm{~min}$, incubation temperature of $50{ }^{\circ} \mathrm{C}$ and agitation speed of 200 $\mathrm{rpm}$. The best enzyme loading parameter that was determined using Design Expert software was used in the next run of experiments. The experiments were repeated to study the effect of incubation time, followed by incubation temperature. The incubation times were varied from 30, 83, 135, 188 and $240 \mathrm{~min}$ to study the influence of incubation time on the sawdust hydrolysis; while the incubation temperatures were varied from $30{ }^{\circ} \mathrm{C}, 42.5{ }^{\circ} \mathrm{C}, 55^{\circ} \mathrm{C}, 67.5{ }^{\circ} \mathrm{C}$ and $80{ }^{\circ} \mathrm{C}$. All the experiments were done in triplicates.

\section{SEM analysis of pre-treated sawdust}

The surface structure of untreated and pretreated sawdust was performed by using a Scanning Electron Microscopy (SEM) instrument (Nova nanoSEM; Fei CO., Hillsboro, OR) with the Everhart Thornley detector. The structure was performed at $5 \mathrm{kV}$ and images were taken at magnifications of $2000 \times$. The air-dried samples were mounted on aluminium stubs and sputter coated with gold in the presence of argon gas with a Hummer 1 sputter coater [17].

\section{EXPERIMENTAL RESULTS}

\section{Impact of pretreatment on the sawdust (SD)}

Figure 3 shows the xylose production on the untreated and five autoclaved cycle sawdust at $121{ }^{\circ} \mathrm{C}$. The result indicated that the xylose concentration of untreated sawdust to be $0.11 \mathrm{mg} / \mathrm{mL}$ while the fifth autoclaved sawdust gave the highest xylose concentration of $0.61 \mathrm{mg} / \mathrm{mL}$, which was relatively 5.5 -fold higher than the untreated sawdust. There was only a slight increment of xylose production in the first autoclaved sawdust at $0.26 \mathrm{mg} / \mathrm{mL}$ which was 2.36 -fold higher than untreated sawdust. On the other hand, the xylose production for the first until forth cycle autoclaved sawdust did not show obvious increment, with 2.3-2.5-fold higher than the untreated sawdust.

Amini et al. [1] reported that the thermal softening temperature of hard and softwood is at $180{ }^{\circ} \mathrm{C}$. Moreover, the high pretreatment temperature of $150-170{ }^{\circ} \mathrm{C}$ is well established for xylan breakdown [29]. However, furfural was produced at these temperature as a product converted from the xylose and xylan [24]. Therefore, the lower temperature yet long residence times benefits the yield of sugars (xylose). In this experiment, all hardwood SD samples were autoclaved with different cycles. The operation temperature and time for each autoclave cycle was $121^{\circ} \mathrm{C}$ and 20 min respectively. The result showed that the fifth cycle autoclaved $\mathrm{SD}\left(121^{\circ} \mathrm{C}, 100 \mathrm{~min}=1.7 \mathrm{hr}\right)$ had the highest xylose production of 0.61 $\mathrm{mg} / \mathrm{mL}$. This is because more xylan in the hemicellulose was released into the medium during the pretreatment (autoclave) [8]. It was also stated that the best xylan recovery in liquid was at $120^{\circ} \mathrm{C}$. Another research had also reported that the efficient pretreatment of biomass at mild temperature $\left(100-130{ }^{\circ} \mathrm{C}\right)$ can achieve high conversion of xylan to xylose with the duration time of $1.0 \mathrm{hr}$ [29]. 
These results were further supported by the Scanning Electron Microscopy (SEM) on the untreated and pre-treated sawdust.

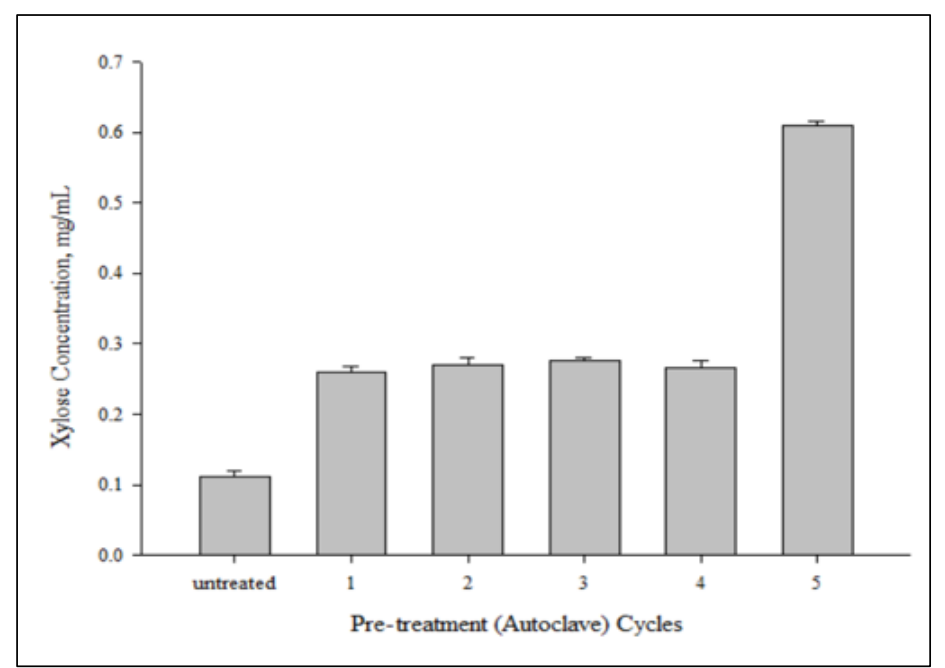

Figure 3. Xylose production using autoclaved sawdust. Standard error is $\leq 0.05$.

\section{SEM Analysis of untreated and pre-treated sawdust}

Figure 4 shows the surface structure of the untreated and pre-treated sawdust performed by the Scanning Electron Microscopy (SEM) with the magnification of 2,000×. Based on the images in Figure 4, the surface structure of the sawdust changed from smooth surface and less broken parts to rough surface and more broken parts (refer Figure 4a-f). The surface structure became more rough and showed shrinkage, with some holes formed in the fifth autoclaved cycle.
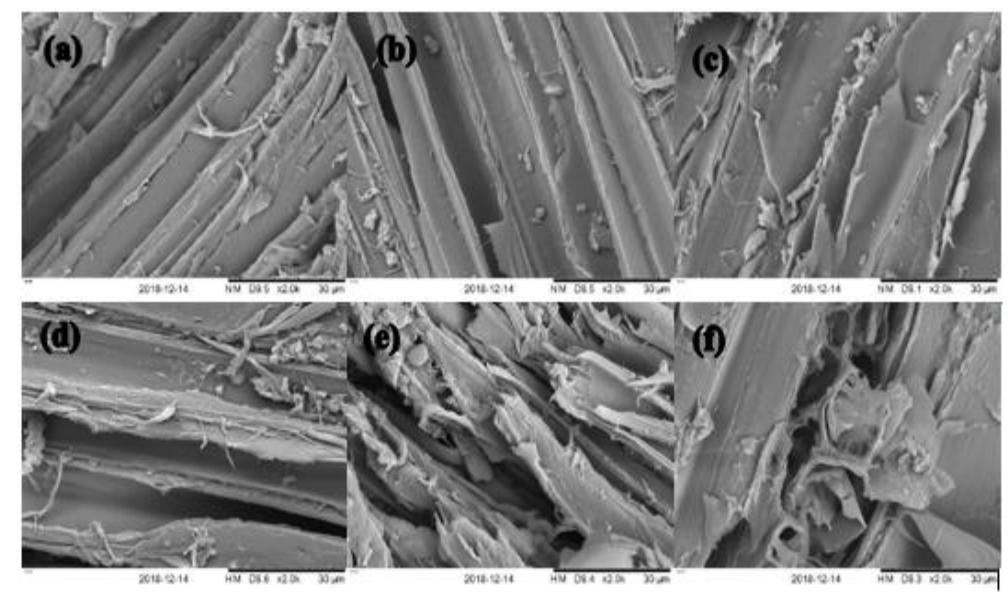

Figure 4. SEM images of sawdust (a) untreated, (b) First pretreatment cycle, (c) Second pretreatment cycle, (d) Third pretreatment cycle, (e) Forth pretreatment cycle, (f) Fifth pretreatment cycles with magnification of 2,000x.

The shrinkage and hole formation of the surface (cell wall) were due to the breakdown of lignin and release of hemicellulose [13, 17]. Besides, the formation of holes will make the structure suitable for the enzymatic hydrolysis process due to higher exposure of hemicellulose [16]. Thus, it resulted in the 5.5-fold higher of xylose production in fifth cycle autoclaved sawdust compared to untreated sawdust as aforementioned. in section 1.1. Moreover, the structure changes from first to fourth pretreatment cycles were not obvious and as a result, the xylose production in first to fourth cycle autoclaved sawdust did not show obvious changes too.

\section{Xylose production on autoclaved sawdust with enzymatic hydrolysis}

Figure 5 shows the xylose production on autoclaved sawdust with and without enzymatic hydrolysis at $50{ }^{\circ} \mathrm{C}$ of incubation temperature and $5 \mathrm{~min}$ of incubation time. Based on the graph shown, the xylose production was increased with the enzymatic hydrolysis by bacterial xylanase. This was proven by the increment on the xylose production in untreated sawdust from $0.11 \mathrm{mg} / \mathrm{mL}$ to $0.14 \mathrm{mg} / \mathrm{mL}$ while the fifth cycle autoclave sawdust increased from $0.61 \mathrm{mg} / \mathrm{mL}$ to $0.71 \mathrm{mg} / \mathrm{mL}$. The first until fourth cycle autoclaved sawdust had an increment $0.26-0.28 \mathrm{mg} / \mathrm{mL}$ to $0.27-0.31 \mathrm{mg} / \mathrm{mL}$. Therefore, in overall, there was an average increment of $14.0 \%$ for the xylose production with the enzymatic hydrolysis. 


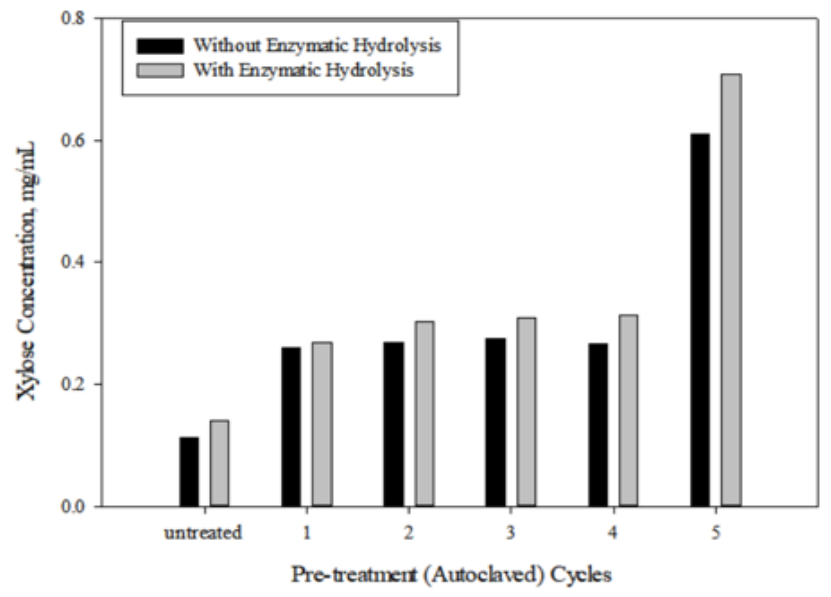

Figure 4. Xylose production on autoclaved sawdust with and without enzymatic hydrolysis in $\mathrm{mg} / \mathrm{mL}$ with standard error $\leq 0.05$.

The result proved that the use of enzymatic hydrolysis process is useful in increasing xylose production. This is because the xylan with the $\beta-1,4-\mathrm{D}$-xylosidic linkages were broken down by the bacterial xylanase $[4,30]$.

\section{Effect of enzyme loading on autoclaved sawdust}

Figure 6 shows the effect of enzyme loading (1\% v/v-18.65 U, 2\% v/v-37.3 U, 3\% v/v-55.95 U, $4 \% \mathrm{v} / \mathrm{v}-74.6 \mathrm{U}, 5 \%$ $\mathrm{v} / \mathrm{v}-93.25 \mathrm{U}$ ) on the fifth cycle autoclaved sawdust at the incubation temperature of $50{ }^{\circ} \mathrm{C}$ and incubation time of $30 \mathrm{~min}$. The range was from 30 to 240 minutes, where the value of intervals was provided by the Design Expert. It is shown that the highest yield of xylose was at $1.0 \% \mathrm{v} / \mathrm{v}$ enzyme loading, with $1.38 \mathrm{mg} / \mathrm{mL}$ xylose. The higher the enzyme loading, the lower the xylose production. Then, it stabilised with $1.17 \mathrm{mg} / \mathrm{mL}$ at $5 \% \mathrm{v} / \mathrm{v}$.

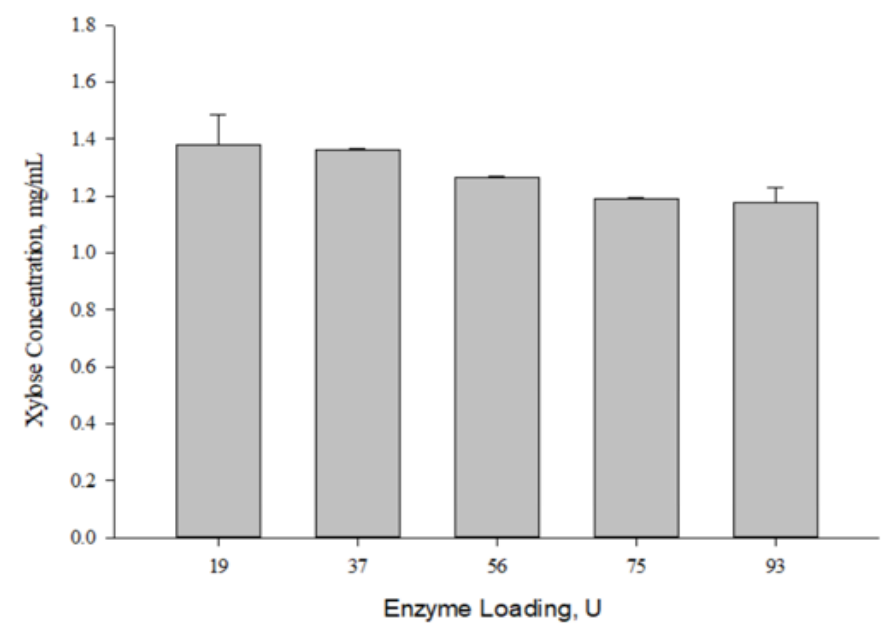

Figure 5. Effect of enzyme loading (\%) on xylose production. Standard error is $\leq 0.05$.

This might due to the significant inhibitory effect of lignin and xylose on enzyme activities [17]. Moreover, the enzyme loadings used in the study by Ko et al. were only 2.5, 5, 10, $40 \mathrm{U}$ and had the highest xylose at $40 \mathrm{U}$ [17]. By comparing with the result shown in Figure 6, the enzyme loading used in this study were in the range of $18.65 \mathrm{U}$ to 93.25 $\mathrm{U}$, which is in a much higher range. Here, the result in the enzyme loading of $1 \%(18.65 \mathrm{U})$ had the highest xylose yield followed by $2 \%$ enzyme loading $(37.3 \mathrm{U})$. The xylose production at $2 \%$ was quite similar with $1.0 \%$ though which might be due to the higher range of enzyme loading in this experiment that caused product inhibition. As the enzyme loading was increased, the xylose concentration continuosly decreased but the changes were slight until the end.

Figure 6 showed the result of data analysis obtained from Design Expert 7.1.6. The result demonstrated that most of the data were in the range of the model. The Analysis of Variance (ANOVA) had analysed and stated that the model of this parameter is a cubic model with $\mathrm{R}^{2}=0.9985$, which indicates the high accuracy of the model as the reading is near to 1.0. The suggested enzyme loading to be used for next section was in the range of $1.04 \%-1.55 \%$. The enzyme loading selected by the software was $1.4 \%(26.11 \mathrm{U})$ with xylose yield of $1.38 \mathrm{mg} / \mathrm{mL}$ with the highest desirability of 1.0 . 


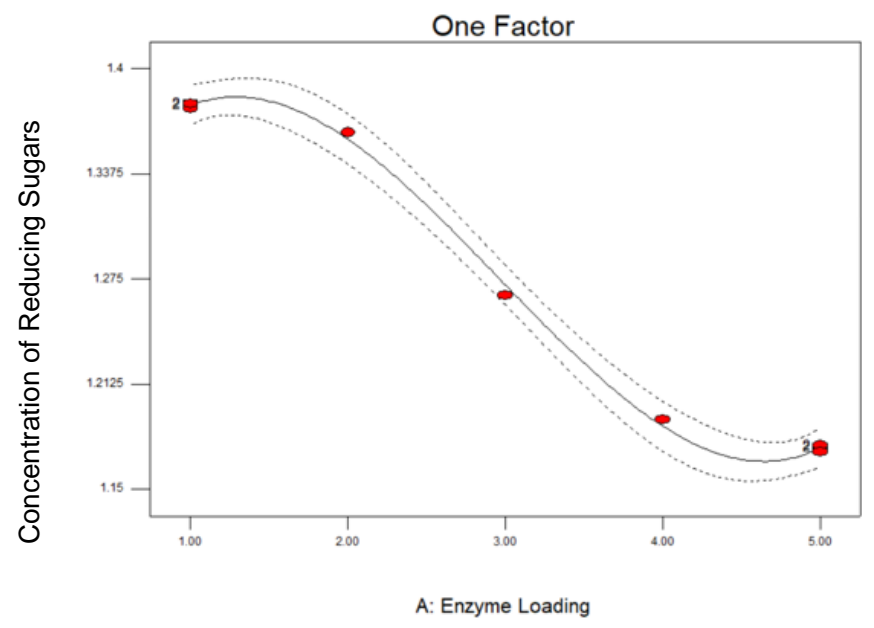

Figure 6. Data analysis obtained from Design Expert 7.1.6.

\section{Effect of incubation time on xylose production of autoclaved sawdust}

The result shown in Figure 8 was the effects of incubation time on xylose production in the fifth cycle autoclaved sawdust with $1.4 \%$ enzyme loading and $50{ }^{\circ} \mathrm{C}$ incubation temperature. The range was from 30 to 240 minutes, where the value of intervals was provided by the Design Expert. The highest xylose production is $1.32 \mathrm{mg} / \mathrm{mL}$ at the incubation time of $30 \mathrm{~min}$. The xylose production decreased as the incubation time increased. Then it stabilized with $1.17 \mathrm{mg} / \mathrm{mL}$ at $240 \mathrm{~min}$.

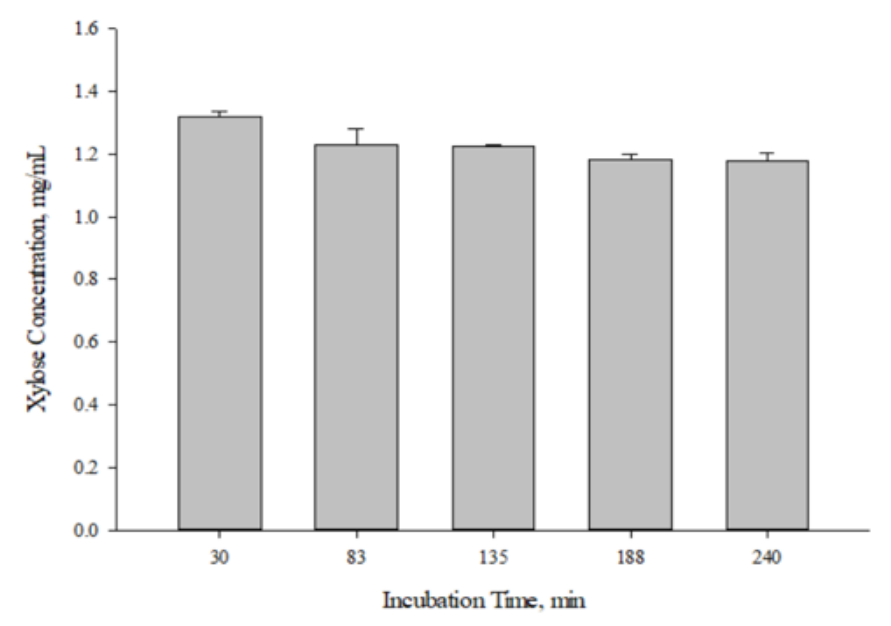

Figure 7. Effect of incubation time ( $\mathrm{min}$ ) on xylose production. Standard error is $\leq 0.05$.

Many researches have been conducted to investigate the effect of incubation time on enzymatic hydrolysis of sawdust, but the range of the incubation time was $10 \mathrm{hr}$ to $72 \mathrm{hr}$. However, this incubation time range was only applied on the untreated sawdust or only first cycle pre-treated sawdust [1, 21, 26] Most researches have stated the result of the highest yield of reducing sugar $(513 \mathrm{mg} / \mathrm{g})$ was at $48 \mathrm{hr}[1,22]$. As stated before, pretreatment with lower temperature and long residence time will have higher xylan recovery in liquid and xylose yield [11, 24]. Therefore, the xylan recovery in fifth cycle autoclaved sawdust had the highest xylan recovery and xylose. Thus, the enzymatic hydrolysis incubation time were decreased as much of the xylan was in liquid form and easily can react with the bacterial xylanase. There was limited research studying on this, therefore further study is required.

The xylose production data was analysed by Design Expert 7.1.6, for which it stated that the model of this parameter was a quadratic model with $\mathrm{R}^{2}=0.9885$. The selected incubation time (highest desirability : 0.960) to be used for next section was $30 \mathrm{~min}$ with $1.32 \mathrm{mg} / \mathrm{mL}$ xylose production in the fifth cycle autoclaved sawdust with $1.4 \% \mathrm{v} / \mathrm{v}$ enzyme loading.

\section{Effect of incubation temperature on xylose production of autoclaved sawdust}

Figure 9 shows the effect of incubation temperature on xylose production in the fifth cycle autoclaved sawdust with $1.4 \% \mathrm{v} / \mathrm{v}$ enzyme loading and $30 \mathrm{~min}$ incubation time. The range was from 30 to $80{ }^{\circ} \mathrm{C}$, where the value of intervals was provided by the Design Expert. From the result, xylose production increased from $1.32 \mathrm{mg} / \mathrm{mL}$ at $30{ }^{\circ} \mathrm{C}$ to the highest 
xylose production of $1.53 \mathrm{mg} / \mathrm{mL}$ at $55^{\circ} \mathrm{C}$. Then xylose production showed slight decrease to $1.37 \mathrm{mg} / \mathrm{mL}$ at $80^{\circ} \mathrm{C}$. Thus, it formed a bell shape as shown in Figure 9.

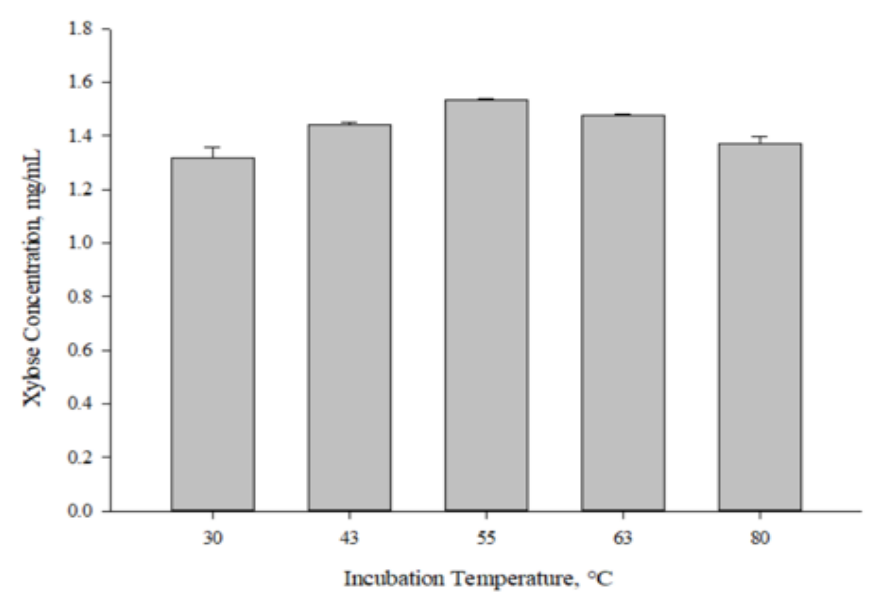

Figure 8. Effect of Incubation Temperature $\left({ }^{\circ} \mathrm{C}\right)$ on Xylose Production. Standard error is $\leq 0.05$.

The highest xylose production at the $55{ }^{\circ} \mathrm{C}$ with the concentration of $1.53 \mathrm{mg} / \mathrm{mL}$ xylose is due to the bacterial xylanase activity and stability. Moreover, the thermostable of the bacterial xylanase from Bacillus sp. had the optimum temperature ranges $50-80{ }^{\circ} \mathrm{C}[3,4,18]$. In addition, the higher the temperature will denature the xylanase, so the production of xylose decreased at the temperature of $80{ }^{\circ} \mathrm{C}$ due to lower enzymatic activity [3]. As for the lower temperature values, they caused the slow activity of the xylanse to carry out enzymatic hydrolysis reaction with the xylan in supernatants.

The data was analysed by Design Expert 7.1.6 and stated that the model of this parameter was a quadratic model with $\mathrm{R}^{2}=0.9676$. The selected incubation temperature (highest desirability: 0.926 ) to be used was $56.9{ }^{\circ} \mathrm{C}$ with $1.52 \mathrm{mg} / \mathrm{mL}$ xylose production in the fifth cycle autoclaved sawdust with $1.4 \% \mathrm{v} / \mathrm{v}$ enzyme loading and 30 min incubation temperature.

\section{CONCLUSION}

The best enzymatic hydrolysis conditions of bacterial xylanase (Bacillus sp.) on hardwood sawdust to produce reducing sugars (xylose) are successfully achieved. The enzyme loading of $1.4 \%$, incubation time of 30 min, and incubation temperature of $56.9^{\circ} \mathrm{C}$ demonstrate the highest xylose production. Under these conditions, $1.52 \mathrm{mg} / \mathrm{mL}$ xylose was produced, which was 2.5 -fold higher than the one without the enzymatic hydrolysis.

Based on the SEM images, repeated cycles of autoclave pretreatment resulted in the shrinkage and holes formed on the sawdust as the hemicellulose of cell wall are released into the media. The fifth cycle autoclaved sawdust shows 5.5fold higher xylose concentration than the untreated sawdust. The use of autoclave pretreatment followed by enzymatic hydrolysis of the sawdust are proven to achieve a more severe overall hydrolyis, thus better prospect to obtain an increased amount of xylose. This knowledge is vital to maximize the production of xylose in the related industries.

For future work, the study ranges of enzyme loading and incubation time could be lowered as the results obtained showed the graph is skewed to the right. For example, enzyme loading could be lowered into the range of $1 \mathrm{U}$ until $40 \mathrm{U}$ while the incubation time could be tested in the range of 5 to $40 \mathrm{~min}$. This is because the fifth cycle hydrolysate used is the media containing higher xylan, thus lesser enzyme and time are needed compared to only one cycle hydrolysate.

\section{ACKNOWLEDGEMENT}

We would like to thank Universiti Malaysia Pahang for providing laboratory facilities and financial assistance via research grant (RDU1603151).

\section{REFERENCES}

[1] N. Amini, V. S. Haritos, and A. Tanksale, "Microwave assisted pretreatment of eucalyptus sawdust enhances enzymatic saccharification and maximizes fermentable sugar yield", Renew. Energy, vol. 127, pp. 653-660, 2018, doi: 10.1016/j.renene.2018.05.001.

[2] P. Bajpai “Chapter 8 Industrial Applications of Xylanases,” Xylanolytic Enymes, pp. 69-104, 2014.

[3] W. Bankeeree, and R. Akada, "Enzymatic Hydrolysis of Black Liquor Xylan by a Novel from a Tropical Strain of Aureobasidium pullulans", Appl. Biochem. Biotechnol., vol 184, pp. 919-934, 2018, doi: 10.1007/s12010-0172598-X.

[4] Y. Bu, Y. Cui, Y. Peng, M. Hu, Y. Tian, Y. Tao, and B. Wu, "Engineering improved thermostability of the GH11 xylanase from Neocallimastix patriciarum via computational library design", Appl. Microbiol. Biotechnol., vol. 102, pp. 3675-3685, 2018, doi: 10.1007/s00253-018-8872-1. 
[5] L. Cao, H. Chen, D. C. W., Tsang, G. Luo, S. Hao, S. Zhang, and J. Chen, “Optimizing xylose production from pinewood sawdust through dilute-phosphoric-acid hydrolysis by response surface methodology", J. Clean. Prod., vol. 178, pp. 572-579, 2018, doi: 10.1016/j.jclepro.2018.01.039.

[6] M., Chen, Q., Li, Y., Zhang, H., Li, J., Lu, Y., Cheng, and H. Wang, "Xylo-oligosaccharides enriched yeast protein feed production from reed sawdust," Bioresour. Technol., vol. 270, pp. 738-741, 2018, doi: 10.1016/j.biortech.2018.09.127.

[7] K. L., Chin, P. S., H'ng, L. J., Wong, B. T., Tey, and M. T. Paridah, "Production of glucose from oil palm trunk and sawdust of rubberwood and mixed hardwood", Appl. Energy, vol. 88, issue 11, pp. 4222-4228, 2011, doi: 10.1016/j.apenergy.2011.05.001.

[8] R., Dune, A., Cayetano, and T. Hyun, "Two-stage processing of Miscanthus giganteus using anhydrous ammonia and hot water for e ff ective xylan recovery and improved enzymatic sacchari fi cation", Bioresour. Technol., vol. 255, pp. 163-170, 2018, doi: 10.1016/j.biortech.2018.01.135.

[9] B., Dutta, A., Banerjee, P., Chakraborty, and R. Bandopadhyay, "Journal of Genetic Engineering and Biotechnology In silico studies on bacterial xylanase enzyme : Structural and functional insight", J. Genet. Eng. Biotechnol., vol. 16, pp. 4-11, 2018, doi: 10.1016/j.jgeb.2018.05.003.

[10] M. G., Godoy, G. M., Amorim, M. S., Barreto, and D. M. G. Freire, “Agricultural Residues as Animal Feed: Protein Enrichment and Detoxification Using Solid-State Fermentation", Current Developments in Biotechnology and Bioengineering. Elsevier B.V., 2016.

[11] W. Gong, L. Dai, H. Zhang, L. Zhang, and L. Wang, “A Highly Efficient Xylan-Utilization System in Aspergillus niger An76: A Functional-Proteomics Study", Front. Microbiol., vol. 9, pp. 1-15, 2018, doi: 10.3389/fmicb.2018.00430.

[12] P. Held, and B. Instruments, "Enzymatic Digestion of Polysaccharides Part II: Optimization of Polymer Digestion and Glucose Production in Microplates", 2012.

[13] E. Husson, T. Auxenfans, M. Herbaut, M. Baralle, V. Lambertyn, H. Rakotoarivonina, and C. Sarazin, "Sequential and simultaneous strategies for biorefining of wheat straw using room temperature ionic liquids, xylanases and cellulases", Bioresour. Technol., vol. 251, pp. 280-287, 2018, doi: 10.1016/j.biortech.2017.12.047.

[14] N. Izyan, W. Azelee, J. Jahim, A. Fauzi, S. Fatimah, Z. Mohamad, and R. Illias, "High xylooligosaccharides (XOS) production from pretreated kenaf stem by enzyme mixture hydrolysis”, Ind. Crop. Prod., vol. 81, pp. 11-19, 2016, doi: 10.1016/j.indcrop.2015.11.038.

[15] Kilpelainen. "Pressurised hot water extraction of acetylated xylan from birch sawdust", Nordic Pulp and Paper Research Journal, vol., 27, pp. 680-688, 2012, doi: 10.3183/npprj-2012-27-04-p680-688.

[16] B. Kim, I. Gulati, J. Park, and J. S. Shin, "Pretreatment of cellulosic waste sawdust into reducing sugars using mercerization and etherification", BioResources, vol. 7, no. 4, pp. 5152-5166, 2012, doi: 10.15376/biores.7.4.5152-5166.

[17] J. K. Ko, Y. Kim, E. Ximenes, and M. R. Ladisch, "Effect of liquid hot water pretreatment severity on properties of hardwood lignin and enzymatic hydrolysis of cellulose", Biotechnol. Bioeng., vol. 112, no. 2, pp. 252-262, 2015, doi: 10.1002/bit.25349.

[18] V. Kumar, A., Kumar, and D. Pratyoosh, "Engineering Thermostable Microbial Xylanases Toward its Industrial Applications", Mol. Biotechnol., vol. 60(3), pp. 226-235, 2018, doi: 10.1007/s12033-018-0059-6

[19] N., Masngut, S., Manap, R., Che Man, and S. Shaarani, "Bacteria Isolation from Landfill for Production of Industrial Enzymes for Waste Degradation", Ind. J. Sci. Technol., vol. 10(7), pp. 1-5, 2017, doi: 10.17485/ijst/2017/v10i7/111224.

[20] P. D., Muley, and D. Boldor, "Advances in biomass pretreatment and cellulosic bioethanol production using microwave heating”, pp. 27-30, 2017, doi: 10.18690/978-961-286-048-6.18.

[21] K., Pandiyan, R., Tiwari, S., Singh, P. K. S., Nain, S., Rana, A., Arora, L. Nain, “Optimization of Enzymatic Saccharification of Alkali Pretreated Parthenium sp . using Response Surface Methodology", vol. 2014, 2014, doi: 10.1155/2014/764898.

[22] J. Pickles, "Thermal Softening And Degradation”, 1971.

[23] A. Rosli, "Isolation of Solubilizing Microorganisms from Landfill Soil”, 2017.

[24] C. Sener, A. H. Motagamwala, D. M. Alonso, J. A. Dumesic, "Enhanced Furfural Yields from Xylose Dehydration in the V-Valerolactone/Water Solvent System at Elevated Temperatures", ChemSusChem. Vol. 11, issue 14, pp. 2321-2331, 2018, doi: 10.1002/cssc.201800730.

[25] N. Shahi, A. Hasan, S. Akhtar, M. H. Siddiqui, and U. Sayeed, "Xylanase: A promising enzyme Xylanase : A promising enzyme", 2016.

[26] A. Sridevi, G. Narasimha, G. Ramanjaneyulu, K. Dileepkumar, B. R. Reddy, and P. S. Devi, "Saccharification of pretreated sawdust by Aspergillus niger cellulase", 3 Biotech, vol. 5(6), pp. 883-892, 2015, doi: 10.1007/s13205015-0284-7.

[27] S. S. M. Sukri, and A. M. Mimi Sakinah, "Production of High Commercial Value Xylooligosaccharides from Meranti Wood Sawdust Using Immobilised Xylanase”, Appl. Biochem. Biotechnol., vol. 184(1), pp. 278-290, 2018, doi:10.1007/s12010-017-2542-0.

[28] M. A. Sulaiman, K. Muthusamy, S. M. Aris, S. M. Aris, K. Muthusamy, and A. M. A. Budiea, "Two-fold sustainability - Adobe with sawdust as partial sand replacement”, IOP Conf. Ser. Mater. Sci. Eng., vol. 342, 2018, 
doi: 10.1088/1757-899X/342/1/012069.

[29] H. Wei, X. Chen, J. Shekiro, E. Kuhn, W. Wang, Y. Ji, and M. P. Tucker, "Kinetic Modelling and Experimental Studies for the Dilute-Acid Pretreatment and Subsequent Enzymatic Hydrolysis", Catalysts, vol. 8, issue 1, 2018, doi: 10.3390/catal8010039.

[30] S. You, C. C. Chen, T. Tu, X. Wang, R. Ma, H. Cai, and H. Luo, "Insight into the functional roles of Glu175 in the hyperthermostable xylanase XYL10C - $\Delta \mathrm{N}$ through structural analysis and site - saturation mutagenesis", Biotechnol. Biofuels, pp. 1-12, 2018, doi:10.1186/s13068-018-1150-8.

[31] L. Zhang, and H. Yu, "Conversion of xylan and xylose into furfural in biorenewable deep eutectic solvent with trivalent metal chloride added", BioRes., vol. 8(4), pp. 6014-6025, 2013, doi: 10.15376/biores.8.4.6014-6025. 